\title{
Phenotypic and Functional Comparison of Class Switch Recombination Deficiencies with a Subgroup of Common Variable Immunodeficiencies
}

\author{
Daan J. aan de Kerk ${ }^{1,2}$ • Machiel H. Jansen ${ }^{1,2}$ • Stephen Jolles ${ }^{3}$ - Klaus Warnatz ${ }^{4}$. \\ Suranjith L. Seneviratne ${ }^{5} \cdot$ Ineke J. M. ten Berge $^{6} \cdot$ Ester M. M. van Leeuwen $^{2}$ • \\ Taco W. Kuijpers ${ }^{1}$
}

Received: 31 January 2016 / Accepted: 18 July 2016 /Published online: 2 August 2016

(C) The Author(s) 2016. This article is published with open access at Springerlink.com

\begin{abstract}
Primary antibody deficiencies (PADs) are the most common immunodeficiency in humans, characterized by low levels of immunoglobulins and inadequate antibody responses upon immunization. These PADs may result from an early block in B cell development with a complete absence of peripheral $\mathrm{B}$ cells and lack of immunoglobulins. In the presence of circulating B cells, some PADs are genetically caused by a class switch recombination (CSR) defect, but in the most common PAD, common variable immunodeficiency (CVID), very few gene defects have as yet been characterized despite various phenotypic classifications. Using a functional read-out, we previously identified a functional subgroup of CVID
\end{abstract}

Electronic supplementary material The online version of this article (doi:10.1007/s10875-016-0321-2) contains supplementary material, which is available to authorized users.

Daan J. aan de Kerk

d.j.aandekerk@amc.nl

1 Department of Pediatric Hematology, Immunology and Infectious Diseases, Academic Medical Center (AMC),

Amsterdam, The Netherlands

2 Department of Experimental Immunology, AMC, Amsterdam, The Netherlands

3 Department of Immunology, University Hospital of Wales Heath Park Cardiff, Cardiff, UK

4 Department of Rheumatology and Clinical Immunology, University Medical Centre Freiburg, Freiburg, Germany

5 Department of Immunology, Royal Free London NHS Foundation Trust, London, UK

6 Department of Internal Medicine, AMC, Amsterdam, The Netherlands patients with plasmablasts (PBs) producing IgM only. We have now further characterized such CVID patients by a direct functional comparison with patients having genetically wellcharacterized CSR defects in CD40L, activation-induced cytidine deaminase (AID) and uracil $\mathrm{N}$-glycosylase activity (UNG). The CSR-like CVID patients showed a failure in B cell activation patterns similar to the classical AID/UNG defects in three out of five CVID patients and distinct more individual defects in the two other CVID cases when tested for cellular activation and PB differentiation. Thus, functional categorization of $\mathrm{B}$ cell activation and differentiation pathways extends the expected variation in CVID to CSR-like defects of as yet unknown genetic etiology.

Keywords Primary antibody deficiencies · class switch recombination defect $\cdot$ common variable immunodeficiency . $\mathrm{B}$ cells

\section{Introduction}

Primary immunodeficiencies (PIDs) are well recognized in the Western world [1-3]. About $65 \%$ of these PIDs show an altered antibody production, categorized as primary antibody deficiency (PAD). PADs can be caused by either a combined T and B cell defect or a B cell-intrinsic defect. Among B cellintrinsic defects, at least five distinct groups are being recognized, namely defects in the B cell development, migration, activation, class switch recombination (CSR), and survival. Despite this classification, many of the PADs remain without a clear etiology [4].

The most prevalent of the PAD diagnoses is common variable immunodeficiency (CVID), an antibody deficiency caused by B cell dysfunction. The etiology of CVID seems 
to have a complex genetic cause, although few monogenetic causes may explain a CVID-like phenotype (e.g., TACI, ICOS, CD19, CD20, and BAFFR) $[4,5]$.

Twenty-fold less common than CVID are the so-called hyper-IgM syndromes (HIGM) or class switch recombination (CSR) defects, which are characterized by a low-to-normal or elevated serum IgM in the absence of any other immunoglobulin (Ig) isotypes in the serum. A number of unique gene defects (e.g., in $C D 40 L, C D 40, A I C D A, U N G$, and $I K B K G$ ) have been identified that lead to a defect in the CSR mechanism required for the transition of the initial low-affinity IgM to an Ig isotype of increased affinity $[6,7]$.

Defects in CD40L (TNFSR5 or CD154) encoded by the Xlinked $C D 40 L$ gene represented the first reported CSR defect. Identical abnormalities, both clinically as well as immunologically, have more recently been identified in the autosomalrecessive syndrome of mutations in the gene for its counterreceptor CD40 on B cells. In both syndromes, the lack of functional expression of the surface molecule, leads to the failure of a proper B cell-T cell signaling contact at the interphase of germinal centers where a subset of primary activated lymphocytes, i.e., the $\mathrm{T}$ follicular helper cells (Tfh) and naïve $\mathrm{B}$ cells meet in the lymph nodes, mucosal lymphoid tissues, or marginal zones of white pulp in the spleen [8]. After successful interaction between antigen-specific Tfh cells and B cells, the B cells start to proliferate and initiate a cell-intrinsic process of Ig affinity maturation by class switch and hypermutation, in which B cell-specific enzymes such as activation-induced cytidine deaminase or AID (encoded by $A I C D A$ ) and uracil $\mathrm{N}$-glycosylase activity (encoded by $U N G)$ are involved [9-11].

Within the diagnosis and definitions of CVID, there are many overlapping features with CSR-defects. This is also recognized in the list of clinical criteria provided by the European Society for Immunodeficiencies (ESID). In CVID, the initial steps of B cell development in the bone marrow are supposed to have normally proceeded. In most patients, there are mature B cells circulating but in vivo antibody production fails. Many studies have tried to classify these unidentified defects in different subtypes of CVID using phenotyping and a description of the B cell recombination history [12-17].

We have previously used a comprehensive culture system to characterize CVID in functional terms by the capacity of the patient's B cells to proliferate and differentiate into Ig-secreting plasmablasts (PBs) [15]. In this way, we have identified a subgroup of CVID patients, which was highly reminiscent of CSR-like B cell defects. Since this subgroup of CVID patients has not been well described, we have further characterized their B cell functions in greater detail as a separate group and compared the results of these CVID patients to those of patients with genetically well-defined CSR-defects.

\section{Materials and Methods}

Samples This study was approved by the Medical Ethics Committee of the Academic Medical Center (Medisch Ethische Toetsingscommissie AMC) in Amsterdam, and was performed in accordance with the Declaration of Helsinki.

Heparinized peripheral blood samples from patients suspected or diagnosed with CVID were collected for routine diagnostics. Cord blood samples from healthy term-newborn donors were collected by nurses from the maternity ward with parental consent, all samples were collected anonymously for the authors and none of the authors had access to clinical data, samples were used in accordance with the Dutch law regarding the use of discarded material for research purposes. Healthy adult control samples $(n=20)$ were available from buffy coats obtained from Sanquin blood bank Amsterdam, all samples were acquired anonymously. None of the authors had access to clinical data from any control samples. PBMCs were isolated using standard density gradient centrifugation techniques using Lymphoprep (Nycomed, Oslo, Norway) and stored in liquid nitrogen until use. The CSR-deficient patients were identified via clinical presentation and corresponding diagnosis by gene analysis (of CD40L, CD40, AID, or UNG) by classical Sanger sequencing, all CVID patients were negative for these defects.

Flow Cytometry PBMCs were resuspended in phosphatebuffered saline (PBS), containing $0.5 \%(w / v)$ BSA and $0.01 \%$ sodium azide. PBMCs were incubated with saturating concentrations of fluorescently labeled conjugated monoclonal antibodies (MoAbs). Analysis of cells was performed using a FACSCanto-II flowcytometer and FlowJo software. The following directly conjugated MoAbs were used for flow cytometry: CD19-PerCP-Cy 5.5, CD19 Alexa-700, CD20APC, CD20-PerCP-Cy 5.5, CD38 PE-Cy7, CD138 APC, IgG-PE, IgD-PE, and IgA-PE from BD-biosciences (San Jose, USA), CD27-FITC from Sanquin (Amsterdam, the Netherlands), IgM-PE from ITK-diagnostics (Uithoorn, the Netherlands).

B Cell Activation In Vitro PBMCs were resuspended in PBS at a concentration of $5-10 \times 10^{6}$ cells $/ \mathrm{ml}$ and labeled with $0.5 \mu \mathrm{M}$ carboxyfluorescein succinimidyl ester (CFSE) (Molecular Probes) in PBS for $10 \mathrm{~min}$ at $37^{\circ} \mathrm{C}$ under constant agitation. Cells were washed and subsequently resuspended in IMDM supplemented with $10 \%$ fetal calf serum (BioWhittaker), antibiotics, and 3.57 $\times 10-4 \%(v / v) \beta-$ mercapto-ethanol (Merck). Labeled PBMCs containing a fixed number of $\mathrm{B}$ cells $\left(1 \times 10^{5}\right.$ per well $)$ were cultured in 48-well flat-bottomed plates for 6 days at $37{ }^{\circ} \mathrm{C}$ and stimulated with saturating amounts of $5 \mu \mathrm{g} / \mathrm{ml}$ anti-IgM mAb (clone MH15; Sanquin), 1:500 anti-CD40 mAb ascites (clone 14G7; 
Sanquin), $20 \mathrm{ng} / \mathrm{ml} \mathrm{IL-21} \mathrm{(Invitrogen),} \mathrm{or} 1 \mu \mathrm{g} / \mathrm{ml} \mathrm{CpG}$ oligodeoxynucleotide 2006 (Invivogen), with 100 U/ml IL-2 (R\&D Systems). Proliferation of the B cells was assessed by measuring CFSE dilution by flow cytometry.

IgG and IgM ELISA Supernatants were tested for secreted IgM and IgG with an in-house ELISA using polyclonal rabbit anti-human IgG and IgM reagents and a serum protein calibrator all from Dako (Heverlee, Belgium), as described before [15]

Statistics Differences between immunoglobulin levels were calculated by two-sided, two-tailed Student's $t$ test. For correlations, the Spearman nonparametric correlation test was used. $P<0.05$ was considered statistically significant.

\section{Results}

\section{Patient Selection}

Using our previously described experimental conditions for B cell activation [15], we have to date functionally screened over 40 PAD patients who were suspected or diagnosed with CVID by their clinicians because of their clinical presentation, low serum IgG and IgA, and a lack of humoral response to polysaccharides at presentation.

With this screening assay, we selected a small series of patients who were considered CSR-like CVID cases because of an increased IgM in their serum at diagnosis (more than 2SD above the cutoff for normal values measured at least two times apart) and/or documented "IgM-only" immunoglobulin isotype production in vitro (Tables 1 and 2).

When categorized according to the Freiburg, Paris, and EUROclass classification [17], these CSR-like CVID patients fitted in the B+CVID patient category with a variable number of memory $\mathrm{B}$ cells but without a significant expansion of transitional B cells (Table 3).

These selected CVID patients had normal T cell numbers and function upon $\mathrm{T}$ cell activation toward anti-CD3, antiCD3/anti-CD28, IL7, or IL15, as indicated in proliferation assays as described previously (data not shown).

\section{Normal Peripheral Blood B Cell Phenotypes}

Within the B cell compartment $\left(\mathrm{CD} 20^{+} \mathrm{CD} 19^{+}\right)$, various $\mathrm{B}$ cell subsets are routinely distinguished, i.e., transitional $\left(\mathrm{CD} 38^{\text {high }} \mathrm{CD} 24^{\text {high }}\right)$, naïve $\left(\mathrm{sIgD}^{+} \mathrm{CD} 27^{-}\right)$, non-switched $\left(\operatorname{sIgD}^{+} \mathrm{CD} 27^{+}\right)$, and switched memory $\left(\mathrm{sIgD}^{-} \mathrm{CD} 27^{+}\right) \mathrm{B}$ cells. During childhood, the human B cell compartment changes from a completely naive to a more differentiated phenotype as a consequence of the expansion of $\mathrm{CD} 27^{+}$memory $\mathrm{B}$ cells. Within the $\mathrm{CD} 27^{+}$memory B cell compartment, surface immunoglobulin receptor expression can be used to further distinguish $\operatorname{sIgM}^{+}, \operatorname{sIgG}^{+}$, and $\operatorname{sIgA}^{+}$memory B cells [18-20]. In the adult PBMC fractions, the $B$ cell phenotype demonstrates the presence of a clear memory B cell compartment including $\operatorname{sigG}{ }^{+}$and $\operatorname{sgg} \mathrm{A}^{+} \mathrm{B}$ cells, both of which are absent in cord blood PBMCs where all B cells are naïve (Fig. 1 and Supplementary Fig. Fig. 1).

\section{Patients with Classical CSR Defects Show Phenotypic Differences in Peripheral B Cells}

Patients with genetically well-characterized CSR defects were included (Table 2) for comparison with the five CSR-like CVID patients mentioned earlier (Table 1). Next to cord-blood samples and healthy adult samples, we immunophenotyped the classical CSR cases to directly compare with the CSR-like CVID patients (Table 3). As reported before [8], the circulating B cells in patients with $C D 40 L$ gene defects consisted of naïve $B$ cells only and no memory B cells. These patients did have a slightly increased number of transitional B cells, similar to cord blood samples. On the other hand, patients who suffered from defects in AICDA showed normal numbers of non-switched $B$ cells and even some memory $\operatorname{sigD}{ }^{-} \mathrm{CD} 27^{+} \mathrm{B}$ cells that had not undergone any class switching, i.e., these cells did not show any sIgG or $\operatorname{sIg} \mathrm{A}$ expression and expressed $\operatorname{sig} M$ only. Similar to patients with an $A I C D A$ gene defect, the individual that had been identified with an $U N G$ gene defect [15], contained non-switched $\operatorname{sIgM}^{+} \mathrm{B}$ cell population in the absence of $\operatorname{sIgD}^{-} \mathrm{CD} 27^{+} \mathrm{B}$ cells, indicating a lack of switched $\operatorname{sIgG}^{+}$and $\operatorname{sIgA}^{+}$memory $\mathrm{B}$ cells (Table 3).

\section{Plasmablast Formation Upon Activation of Healthy B Cells}

The capacity of the B cells to proliferate and differentiate upon in vitro activation in a 6-day culture was tested with $\mathrm{CpG}$ in the presence of a small $\mathrm{B}$ cell activating dose of IL-2 (to which purified $\mathrm{T}$ cells do not show proliferation and cytokine induction and acts by direct $\mathrm{B}$ cell activation of the IL-2 receptor) $[15,21]$. T cell-dependent $\mathrm{B}$ cell stimulation was mimicked by the combination of antibodies against SIgM to trigger the B cell antigen-receptor (BCR) on the majority of circulating $\mathrm{B}$ cells in the blood, together with costimulatory CD40 activation and Tfh cell-associated IL-21 $(\alpha \operatorname{IgM} / \alpha \mathrm{CD} 40 / \mathrm{IL}-21)$ [22]. To check for the $\mathrm{T}$ cell function and the indirect effects of $\mathrm{T}$ cell proliferation on subsequent $\mathrm{B}$ cell activation, we also stimulated the PBMCs with the combination of $\mathrm{T}$ cell-specific $\alpha \mathrm{CD} 3 / \alpha \mathrm{CD} 28 \mathrm{MoAbs}$, in which the common-gamma 
Table 1 Clinical characteristics for CSR-like CVID patients at presentation

\begin{tabular}{|c|c|c|c|c|c|}
\hline Patient & $\# 1$ & $\# 2$ & $\# 3$ & $\# 4$ & $\# 5$ \\
\hline Year of birth & 1989 & 1939 & 1958 & 1965 & 1944 \\
\hline Gender & Male & Male & Male & Female & Female \\
\hline Age at diagnosis & 18 & 20 & 14 & 41 & 60 \\
\hline \multicolumn{6}{|l|}{ Clinical presentation } \\
\hline & Appendicitis & Rec. lung infections & Bronchiectasis & Bronchiectasis & Rec. lung infections \\
\hline & Rec. fever & Tonsillitis & Deafness & ITP & Bronchiectasis \\
\hline & Pneumonia & & Mild mental retardation & Splenomegaly & \\
\hline & Sinusitis & & Dental caries & & \\
\hline \multicolumn{6}{|l|}{ Gene analysis } \\
\hline CD40L & neg & neg & neg & neg & neg \\
\hline CD40 & neg & neg & neg & neg & neg \\
\hline UNG & neg & neg & neg & neg & neg \\
\hline AICDA & neg & neg & neg & neg & neg \\
\hline PI3Kdelta & neg & neg & neg & neg & neg \\
\hline \multicolumn{6}{|l|}{ Immunoglobulins at presentation $(\mathrm{g} / \mathrm{L})$} \\
\hline $\operatorname{IgG}$ & $<0.3$ & $<0.1$ & 1.2 & 2.5 & $<0.3$ \\
\hline $\operatorname{IgM}$ & $<0.03$ & 0.46 & 7.05 & 5.27 & 2.5 \\
\hline $\operatorname{IgA}$ & $<0.04$ & $<0.05$ & $<0.22$ & $<0.22$ & $<0.04$ \\
\hline $\operatorname{IgE}$ & $<2$ & ND & $<2$ & $<2$ & ND \\
\hline \multicolumn{6}{|l|}{ B cell subsets at presentation } \\
\hline IgD+CD27- (naive) & 80.1 & 55.4 & 74 & 92 & 95.9 \\
\hline IgD+CD27+ (non-switched memory) & 12.2 & 42.8 & 18.6 & 5 & 1.3 \\
\hline IgD-CD27+ (switched-memory) & 4.2 & 1 & 0 & 0.7 & 0.2 \\
\hline IgD-CD27- (double negative) & 3.5 & 0.8 & 7.4 & 2.3 & 2.6 \\
\hline
\end{tabular}

Year of birth, patient gender, age at diagnosis, clinical presentation, mutations (neg tested negative), immunoglobulin levels at presentation, and B cell subset at presentation is shown

$N D$ not done, HUS Hemolytic-uremic syndrome, ITP Idiopathic thrombocytopenic purpura

(CD132)-cytokine receptors play an essential role as we had previously described [18].

In control experiments, we showed that upon activation, the adult $\mathrm{B}$ cells proliferated and differentiated into PBs $\left(\mathrm{sIgD}^{-} \mathrm{CD} 27^{++} \mathrm{CD} 38^{++}\right.$) (Fig. 2 and Supplementary Fig. Fig. 2). Cord blood B cells showed similar responses but largely failed to differentiate into PBs after 6 days of stimulation. Both adult and cord blood B cells showed proliferation upon T cell-specific $\alpha \mathrm{CD} 3 / \alpha \mathrm{CD} 28$ stimulation. The $\alpha \mathrm{CD} 3 / \alpha \mathrm{CD} 28$ activation downregulated sIgD only on adult and not the cord blood B cells after 6 days of culture, but PBs expressing high levels of CD27 or CD38 did not develop under these conditions.

\section{Plasmablast Formation Upon CSR-Defective B Cell Activation}

We subsequently analyzed the B cells of the known CSR defect patients. With regard to CD40L-deficient $\mathrm{B}$ cells, these cells proliferated normally upon $\mathrm{CpG} / \mathrm{IL}-$ 2 stimulation but B cells could hardly differentiate into
$\mathrm{CD} 27^{++} \mathrm{CD} 38^{++}$PBs. Stimulation with $\alpha \operatorname{IgM} / \alpha \mathrm{CD} 40 / \mathrm{IL}-$ 21 induced vigorous $B$ cell proliferation without any differentiation into $\mathrm{PBs}$ at all (Tables 4 and 5). Remarkably, the $\alpha \mathrm{CD} 3 / \alpha \mathrm{CD} 28$-mediated $\mathrm{T}$ cell activation failed completely to induce any $\mathrm{B}$ cell proliferation in both CD40L-deficient patients. Identical responses were found in a CD40-deficient patient, demonstrating the importance of CD40L-CD40 interactions (data not shown).

Stimulation of the B cells of AICDA-mutated patients resulted in a different $B$ cell signature in our B cell cultures. Both B cell proliferation and differentiation into PBs were observed upon activation with $\mathrm{CpG} / \mathrm{IL}-$ 2. In contrast, $\alpha \operatorname{IgM} / \alpha C D 40 / \mathrm{IL}-21$ stimulation induced $\mathrm{B}$ cell proliferation but no $\mathrm{PB}$ formation-similar to cord blood B cells and the CD40L- or CD40-deficient $\mathrm{B}$ cell cultures. With $\alpha \mathrm{CD} 3 / \alpha \mathrm{CD} 28$ stimulation, AIDdeficient $B$ cells proliferated normally, but did not downregulate $\operatorname{sgD}$ (in contrast to control adult B cells).

The reactivity of $\mathrm{B}$ cells of the $U N G$-mutated patient was an almost complete functional phenocopy of the 
Table 2 Clinical characteristics for known CSR patients at presentation

\begin{tabular}{|c|c|c|c|c|c|}
\hline Patient & CD40L \#1 & CD40L \#2 & AID \#1 & AID \#2 & UNG \\
\hline Year of birth & 1985 & 1980 & 1975 & 1972 & 1994 \\
\hline Gender & Male & Male & Female & Male & Male \\
\hline Age at diagnosis & 3 & 2 & 20 & 6 & 3 \\
\hline \multicolumn{6}{|l|}{ Clinical presentation } \\
\hline & Bronchiectasis & Rec. neutropenia & Vasculitis & Rec. lung infections & Rec. lung infections \\
\hline & Sinusitis & HUS & Rec. breast abces & Bronchiectasis & Rec. Otitis \\
\hline & Cold sores & & Meningococcal meningitis & & Failure to thrive \\
\hline & Urticaria & & Cutaneous lupus & & \\
\hline \multicolumn{6}{|l|}{ Gene analysis } \\
\hline CD40L & $\begin{array}{l}\text { c. } 464 \mathrm{~T}>\mathrm{C}, \\
\quad \text { (p. Leu155Pro) }\end{array}$ & c. $435 \mathrm{delC}$ & - & - & - \\
\hline UNG & - & - & - & - & c.630_632delCCT \\
\hline AICDA & - & - & c. $156+1 \mathrm{~T}>\mathrm{G}$ & c.317T >C (p. L106P) & - \\
\hline \multicolumn{6}{|l|}{$\begin{array}{r}\text { Immunoglobulins at } \\
\text { presentation }(\mathrm{g} / \mathrm{L})\end{array}$} \\
\hline $\operatorname{IgG}$ & 1.5 & $<0.1$ & $<0.1$ & $<0.1$ & $<0.1$ \\
\hline $\operatorname{IgM}$ & 7.5 & 3.5 & 9.0 & ND & 0.5 \\
\hline $\operatorname{Ig} \mathrm{A}$ & $<0.22$ & $<0.1$ & $<0.1$ & ND & $<0.1$ \\
\hline $\operatorname{IgE}$ & $<2$ & ND & ND & ND & ND \\
\hline \multicolumn{6}{|l|}{ B cell subsets at presentation } \\
\hline IgD+CD27- (naive) & 92 & ND & ND & ND & 68.6 \\
\hline IgD $+\mathrm{CD} 27+$ (non-switched memory) & 7 & ND & ND & ND & 27.4 \\
\hline IgD-CD27+ (switched-memory) & 0 & ND & ND & ND & 2.4 \\
\hline IgD-CD27- (double negative) & 1 & ND & ND & ND & 1.6 \\
\hline
\end{tabular}

AICDA-mutated patients. B cells from the $U N G$-mutated patient showed less proliferation when stimulated with $\alpha \operatorname{IgM} / \alpha \mathrm{CD} 40 / \mathrm{IL}-21$, and showed no differentiation into PBs.
Thus, B cells from patients with CD40L or CD40 CSR defects showed an in vitro pattern of proliferation and differentiation responses different from AID or UNG-defective B cells (Tables 4 and 5).
Table 3 B cell subset characteristics at time of analysis for CSR patients and CSR-like CVID patients

\begin{tabular}{llllll}
\hline B cell subsets & \multicolumn{5}{l}{} \\
\hline Identifier & \%Naive & \%Non-Switched & \%Memory & \%IgD-CD27- & \%Transitional \\
\hline Adult control & $(45-85)$ & $(5-25)$ & $(9.0-35)$ & $(1.3-4.3)$ & $(1.7-3.7)$ \\
Cord blood & $(97-100)$ & $(0.0-1.6)$ & $(0.0-0.2)$ & $(0.1-1.2)$ & $(5.0-12.0)$ \\
CD40L & 94.3 & 4.0 & 0.6 & 0.9 & 7.7 \\
AID & 71.9 & 19.6 & 5.1 & 3.2 & 4.6 \\
UNG & 83.8 & 13.0 & 0.4 & 2.6 & 1.56 \\
Patient \#1 & 80.1 & 12.2 & 4.2 & 3.5 & 1.2 \\
Patient \#2 & 54.9 & 42.5 & 0.9 & 1.5 & 0.1 \\
Patient \#3 & 70.3 & 21.9 & 5.6 & 2.2 & 1.6 \\
Patient \#4 & 92.6 & 1.9 & 0.9 & 4.6 & 3.3 \\
Patient \#5 & 92.5 & 4.5 & 1.4 & 1.6 & 3.2 \\
\hline
\end{tabular}

The range for all different peripheral B cell subsets of adult control $(N=25)$ and cord blood $(N=15)$ samples, with average percentages (mean) of the different B cell subsets for the CSR patients and CSR-like CVID patients (from $N=3-5$ experiments), gated for $\mathrm{CD}_{1} 9^{+}$cells is shown

$N D$ not done 


\section{Adult control}
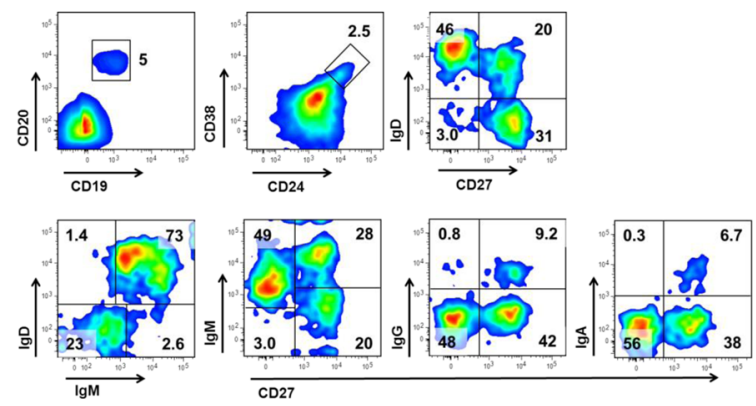

\section{Cordblood}
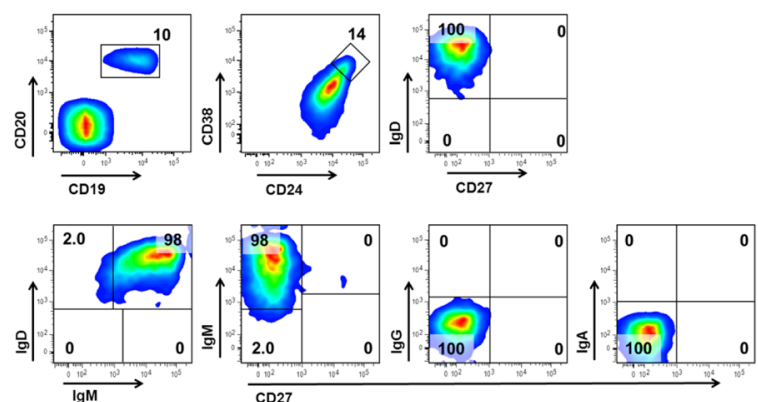

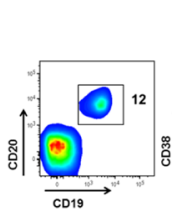

\section{CD40L}

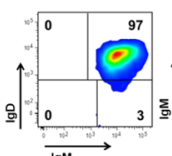

$\stackrel{\lg M}{\longrightarrow}$
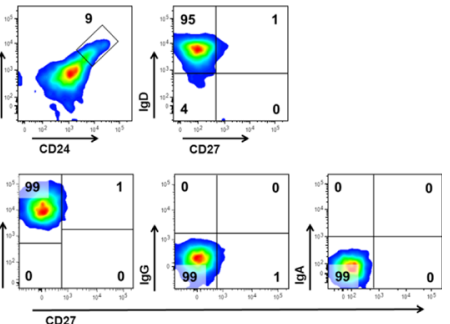

$\underline{\text { AID }}$
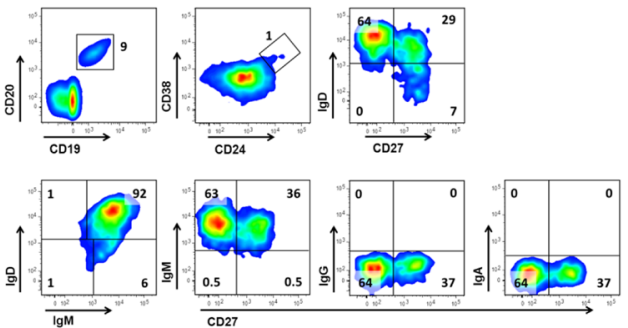

UNG
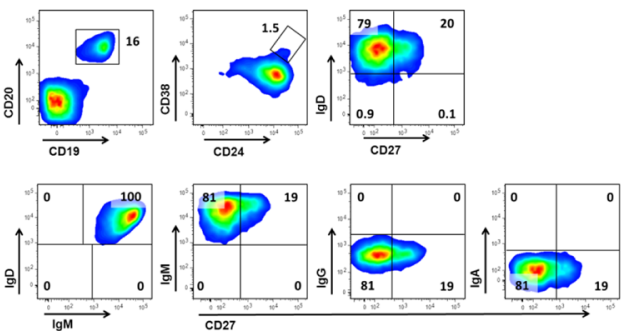

genotyped CD40L-, AID-, and UNG-deficient patients. Numbers indicate mean percentages of multiple experiments in the corresponding quadrant. Healthy adult controls $(N=20)$, healthy cord bloods $(N=15)$, and CD40L-, AID-, and UNG-deficient patients $(N=2-5)$

in vitro for all the conditions tested. In contrast, $\mathrm{CpG} / \mathrm{IL}-2$ stimulation resulted in massive IgM release in 6-day cultures by the cells from patients with mutations in $U N G$ or AICDA, and to a lesser extent by those with the CD40L mutations (Table 4). B cells of patients with an AICDA defect were unique in their capacity to produce $\operatorname{IgM}$ when stimulated with $\alpha \mathrm{CD} 40 / \mathrm{IL}-21$, in contrast to B cells from other genetically characterized CSR defects or from any of the normal controls tested thus far (over 100 individuals to date).

\section{Diagnostic Categorization of Unidentified CSR-like CVID}

The patients had normal or increased serum IgM in vivo, apart from patient \#1, who had no detectable IgM in serum. All patients had circulating B cells that produced relatively large amounts of $\operatorname{IgM}$ without any $\operatorname{IgG}$ and $\operatorname{IgA}$ upon in vitro activation.

Their B cell functionality was compared to the B cell cultures of our patients with known CSR defects (Fig. 3, Tables 4 and 5). One of the selected CSR-like CVID patients had a child with exactly the same immunophenotype and clinical
As expected, none of the B cell cultures performed with PBMCs from CSR-deficient patients produced any IgG 
Adult
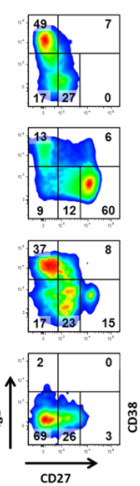

CD40L
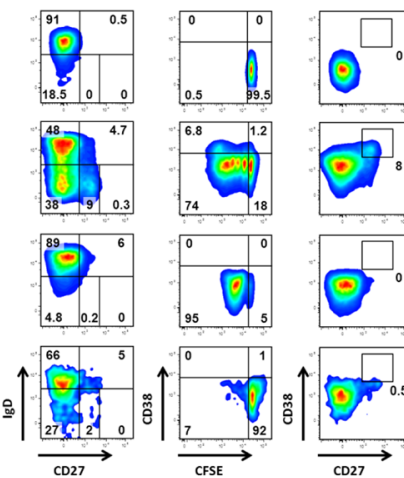

\begin{tabular}{|l|l|}
0 & \\
\hline & 0
\end{tabular}
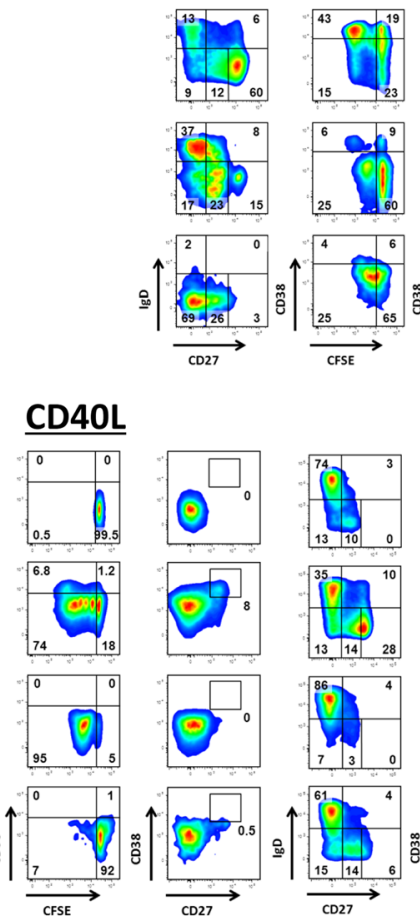
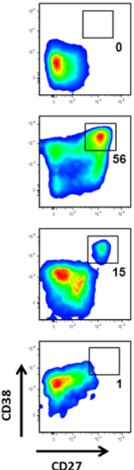

AID
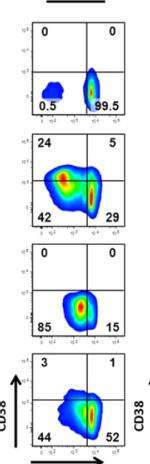

$\stackrel{\text { CFSE }}{\longrightarrow}$

Fig. 2 Proliferation and differentiation of B cells from CSR-deficient patients upon activation. The capacity of B cells from healthy adult controls, healthy cord bloods, and CD40L-, AID-, and UNG-deficient CSR patients to proliferate and differentiate in vitro were tested. CFSElabeled PBMCs were cultured for 6 days, normalized for B cell numbers $\left(1 \times 10^{5} \mathrm{~B}\right.$ cells/well $)$. T cell-independent $\mathrm{B}$ cell activation was tested with $\mathrm{CpG}$ in the presence of IL-2. T cell-dependent B cell stimulation was mimicked by the combinations of $\alpha \operatorname{IgM} / \alpha \mathrm{CD} 40 / \mathrm{IL}-21$. Effect of $\mathrm{T}$ cell

diagnostic features (patient \#2). In all of these patients, classical CSR defects were excluded, i.e., phenotypic or genetic defects in CD40L, CD40, AICDA, UNG, or the recently identified PI3K defects, established in Activated PI3K-p110delta syndrome, types 1 and 2 (APDS- 1 and APDS-2, caused by a number of gain-of-function mutations in $P I K 3 C D$ and $P I K 3 R 1$, respectively) [23-25].

The immunophenotype of the peripheral circulating B cells of these CVID patients was compared to the B cell phenotype of the patients with classical CSR defects (Fig. 4). Three of our patients (patients \#1, \#2, and \#3) looked very similar to those with an $A I C D A$ or $U N G$ defect, i.e., their B cell compartment comprised of naïve and non-switched B cells only, with very few if any switched memory B cells. The other two patients (patients \#4 and \#5) resembled the CD40L-deficient patients, i.e., completely naïve in their B cell compartment without any circulating non-switched and switched $\mathrm{CD} 27^{+}$memory B cells.

Also, after stimulation with $\mathrm{CpG} / \mathrm{IL}-2$ and $\alpha \mathrm{CD} 40 / \mathrm{IL}-$ 21 (Table 4 and 5), our results showed that patients \#1,

\section{Cordblood}
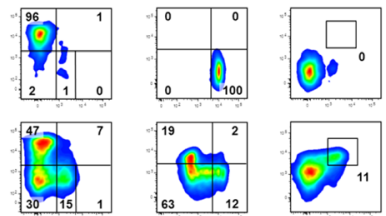

Medium

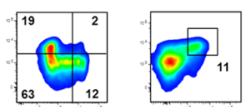

$\mathrm{CpG} / \mathrm{IL}-2$

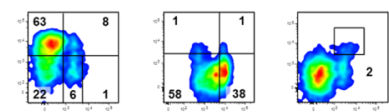

algM/aCD40/IL-21

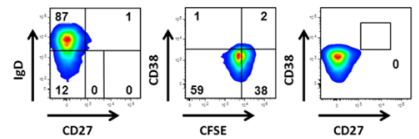

$\mathrm{aCD} 3 / \mathrm{aCD} 28$

UNG
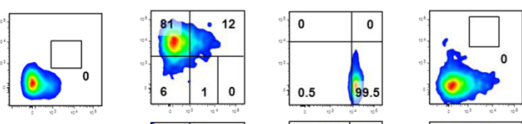

Medium
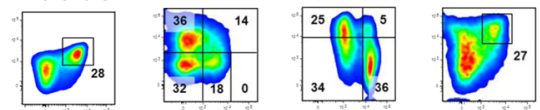

$\mathrm{CpG} / \mathrm{IL}-2$
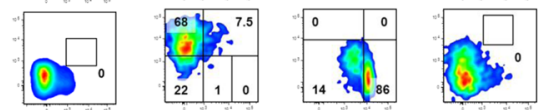

algM/aCD40/IL-21
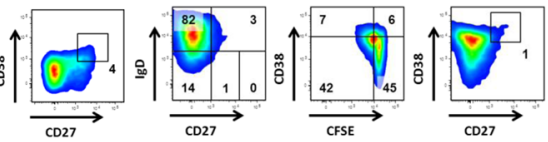

aCD3/aCD28

stimulation was mimicked by $\alpha \mathrm{CD} 3 / \alpha \mathrm{CD} 28$ stimulation, targeting $\mathrm{T}$ cells specifically. Representative FACS plots are shown of B cell subset distribution after 6 days of culture in the presence of the indicated stimuli. Gated on $\mathrm{CD} 19^{+}$lymphocytes to show CFSE dilution indicating proliferation after 6 days of culture, and to demonstrate the emergence of the subsets of Ig-producing B cells, i.e., plasmablasts and/or plasmacells $\left(\mathrm{sIgD}^{-} / \mathrm{CD} 27^{++} / \mathrm{CD} 38^{++}\right)$

\#2, and \#3 mostly resembled the B cell-intrinsic AID/ UNG-deficient patients, i.e., the B cells proliferated under all conditions of $\mathrm{B}$ cell activation tested and induced proper $\mathrm{B}$ cell differentiation and IgM production in vitro upon $\mathrm{CpG} / \mathrm{IL}-2$ activation.

On the other hand, patients $\# 4$ and $\# 5$ behaved differently. Patient \#4 again resembled the CD40Ldeficient patients with a normal proliferation upon $\mathrm{CpG} / \mathrm{IL}-2$ stimulation and $\alpha \mathrm{IgM} / \alpha \mathrm{CD} 40 / \mathrm{IL}-21$ but without any PB differentiation. However, this patient's B cells demonstrated a completely normal $\mathrm{B}$ cell proliferation upon $\mathrm{T}$ cell activation with $\alpha \mathrm{CD} 3 / \alpha \mathrm{CD} 28$ which was absent with CD40L- or CD40-deficient B cells (Fig. 2 and data not shown).

In contrast to the other CSR-like cases as well as the classical CSR patients, the B cells of patient \#5, who presented with an elevated serum IgM upon diagnosis, repeatedly showed a lack of proliferation upon any kind of $\mathrm{B}$ cell stimulation and failed to differentiate to PBs with almost no IgM production $(6-10 \%$ of control 
Table 4 Proliferation, plasmablast differentiation and release of immunoglobulin after 6-day stimulation with $\mathrm{CpG} / \mathrm{IL}-2$ of CSR patients and CSR-like CVID patients

\begin{tabular}{|c|c|c|c|c|c|c|}
\hline \multicolumn{7}{|l|}{$\mathrm{CpG} / \mathrm{IL}-2$} \\
\hline Identifier & Proliferation & CD27++ & CD38++ & CD20dull & IgG & $\operatorname{IgM}$ \\
\hline $\begin{array}{l}\text { Adult } \\
\text { control }\end{array}$ & + & + & + & + & + & + \\
\hline Cord blood & + & $+/-$ & $+/-$ & $+/-$ & - & ++ \\
\hline CD40L & + & $+/-$ & $+/-$ & - & - & $+/-$ \\
\hline AID & + & + & + & + & - & ++ \\
\hline UNG & + & $+/-$ & + & - & - & + \\
\hline Patient \#1 & + & + & + & + & - & ++ \\
\hline Patient \#2 & + & $+/-$ & + & - & - & + \\
\hline Patient \#3 & + & + & + & + & - & $+/-$ \\
\hline Patient \#4 & + & $+/-$ & $+/-$ & - & - & $+/-$ \\
\hline Patient \#5 & $+/-$ & - & - & - & - & $+/-$ \\
\hline
\end{tabular}

Proliferation (measured by CFSE dilution), differentiation into plasmablast (phenotypical markers $\left(\mathrm{CD} 27^{++}, \mathrm{CD} 38^{++}\right.$, and $\left.\mathrm{CD} 20^{\text {dull }}\right)$ ) and release of immunoglobulin into the supernatant (by ELISA) after stimulation with $\mathrm{CpG} / \mathrm{IL}-2$ are scored in comparison with healthy adult controls: ++ (above controls), + (average), +/- (below controls) or (absent). All data shown are gated on the $\mathrm{CD} 19^{+}$B cell population. Adult control $(N=25)$, cord blood $(N=15), \mathrm{CSR}$ patients and CSR-like CVID patients $(N=3-5)$

values) and $\operatorname{IgG}$ (or IgA) production, hence not resembling any of the tested CSR patients.

Table 5 Proliferation, plasmablast differentiation and release of immunoglobulin after 6-day stimulation with aCD40/IL-21 of CSR patients and CSR-like CVID patients

\begin{tabular}{llllllll}
\hline \multicolumn{2}{c}{ aCD40/IL-21 } & & & & & & \\
\hline Identifier & Proliferation & CD27++ & CD38++ & CD20dull & IgG & IgM \\
\hline Adult & + & & + & + & + & + & - \\
$\quad$ control & & & & & & & \\
Cord blood & + & $+/-$ & $+/-$ & $+/-$ & - & - \\
CD40L & + & - & - & - & - & - \\
AID & + & - & - & - & - & $+/-$ \\
UNG & + & - & - & - & - & - \\
Patient \#1 & + & - & - & - & - & $+/-$ \\
Patient \#2 & $+/-$ & - & - & - & - & - \\
Patient \#3 & + & - & - & - & - & ND \\
Patient \#4 & + & - & - & - & - & - \\
Patient \#5 & $+/-$ & - & - & - & - & - \\
\hline
\end{tabular}

Proliferation (measured by CFSE dilution), differentiation into plasmablast (phenotypical markers $\left(\mathrm{CD} 27^{++}, \mathrm{CD} 38^{++}\right.$and $\left.\mathrm{CD} 20^{\text {dull }}\right)$ ) and release of immunoglobulin into the supernatant (by ELISA) after stimulation with aCD40/IL-21 are scored in comparison with healthy adult controls: ++ (above controls), + (average), $+/-$ (below controls) or - (absent). All data shown are gated on the $\mathrm{CD} 19^{+} \mathrm{B}$ cell population. Adult control $(N=25)$, cord blood $(N=15)$, CSR patients and CSR-like CVID patients $(N=3-5)$

\section{Discussion and Conclusions}

We describe a subgroup of patients with CVID identified by a distinct failure of in vitro activation of the $\mathrm{B}$ cells into $\mathrm{IgG} /$ IgA-secreting PBs in the presence of a normal or increased IgM secretion. This defect in Ig class switching is not based on known CSR gene defects. Clinically, these patients were mainly characterized by recurrent infections.

When combining our previously described functional B cell classification with the results of our cultures in a series of patients who had been genetically characterized by one of the currently known CSR defects, we can add an additional layer to identify the possible B cell defects among patients hitherto diagnosed with CVID.

Having determined the B cell reactivity of the most common CSR defects in our culture system by analysis of proliferation, differentiation, and PB formation, we noticed a striking similarity between a subgroup of CVID patients and patients with genetically well-characterized CSR defects. In the subgroup of CSR-like CVID patients, a major T cell defect was excluded by the normal $\mathrm{T}$ cell counts and subsets (naïve, memory, memory-effector $T$ cell subsets according to standard CD45RA/CD27 staining [26]) (Supplementary table 1), as well as their proliferative capacity upon various stimuli including $\alpha \mathrm{CD} 3$ and $\alpha \mathrm{CD} 3 / \alpha \mathrm{CD} 28$ stimulation (data not shown).

The functional data from the CSR-like CVID patients reported here suggest that the failure of $\mathrm{B}$ cells to proliferate and differentiate upon stimulation may be localized at distinct stages of differentiation. One patient identified in this small series of CVID cases best fitted the category of a very early $B$ cell activation defect (patient \#5), because both B cell proliferation and differentiation were clearly defective.

The signal to recombine to a particular switch region comes from the cell surface. Cytokines such as interleukin-21 or IL-4, and appropriate co-stimulation with CD40L induce the production of so-called sterile transcripts from promoters that are upstream of the targeted switch regions. A recent study has highlighted the mechanism of how such transcription through the immunoglobulin switch region produces a non-coding RNA that guides the enzyme AID to DNA in a sequence-specific manner to promote antibody CSR [27].

As had been shown before [28], in vitro stimulation of $\mathrm{B}$ cells that lacked AID resulted in the production of sterile transcripts without CSR. While this recent study from Zheng et al. [27] also suggest that the switch RNA debranching enzyme DBR1 influences CSR, the relative difficulty of performing these experiments in these patient materials did not permit us to further investigate at which steps these CSR-defective CVID patients fail in 

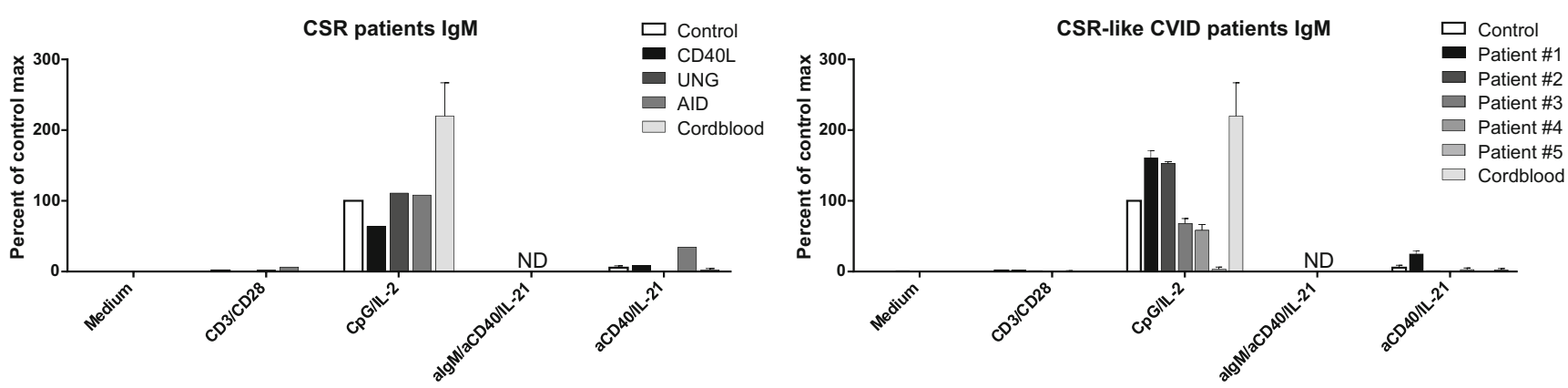

CSR patients IgG
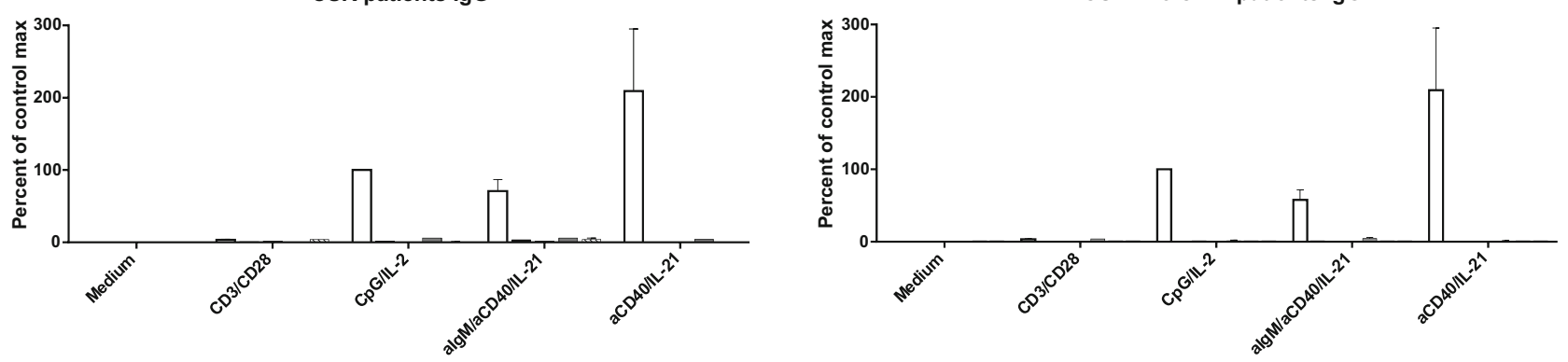

Fig. 3 Production and release of immunoglobulins from CSR-deficient patients and CSR-like CVID patients upon B cell activation. IgM and IgG levels were measured in the supernatants by ELISA after 6 days of culture. Plotting multiple experiments per patient group $(N=2-5)$.

Immunoglobulin production shown is normalized to that of the healthy control samples used in each separate experiment, production of Ig's after stimulated with $\mathrm{CpG} / \mathrm{IL}-2$ is set at $100 \%$. Controls range from 2700 to $5000 \mathrm{pg} / \mathrm{ml}$ for IgG and $4000-9000 \mathrm{pg} / \mathrm{ml}$ for IgM. ND not done

that the CSR failure was not identical. It would be interesting to investigate whether sterile transcripts,

the CSR process. Noticeably, the B cell cultures of our patients reacted differently to stimulation, suggesting

Fig. 4 Representative diagrams of the circulating B cell phenotype at time of analysis. B cell subsets of representative blood samples from a healthy adult control, healthy cord blood, CD40L-, AID-, UNG-deficient CSR patients and five CSR-like CVID patients. Numbers indicate mean percentages of multiple experiments in the corresponding quadrant. Healthy adult controls $(N=20)$, healthy cord bloods $(N=15)$, CD40L-, AID- and UNG-deficient patients $(N=2-5)$, CSR-like CVID patients $(N=2-5)$

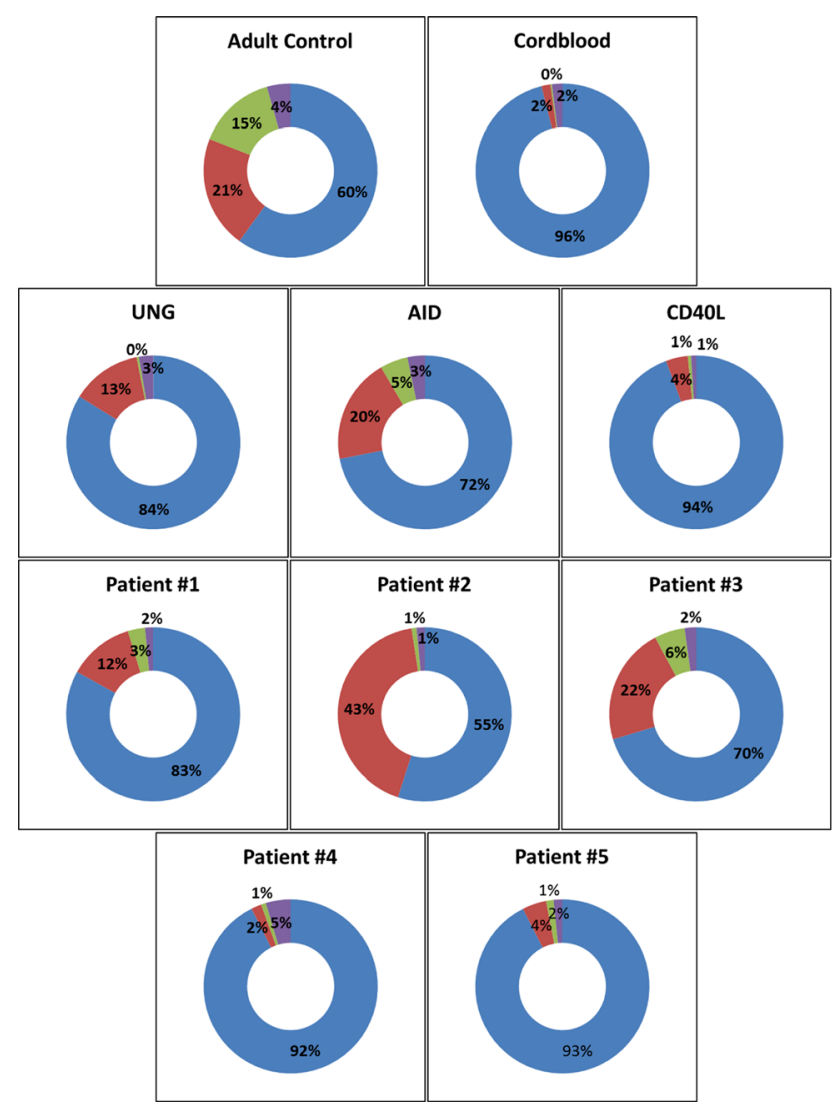

- CD27- IgD+ Naïve B-cells

- CD27+ IgD+ Non-Switched B-cells

a CD27+lgD-Memory B-cells

CD27-IgD-Double Negative B-cells 
SHM, or AICDA expression are normal in these patient $\mathrm{B}$ cells or whether signaling or metabolic processes otherwise determine their failure in CSR activity.

In functional terms, the CD40L-deficient patients and patient \#4 were most similar apart from the defective B cell proliferation after $\alpha \mathrm{CD} 3 / \alpha \mathrm{CD} 28$-mediated $\mathrm{T}$ cell activation when $\mathrm{CD} 40 \mathrm{~L}$ is deficient. We have observed a similar lack of $\alpha \mathrm{CD} 3 / \alpha \mathrm{CD} 28$-mediated $\mathrm{B}$ cell response in leaky X-CID patients with hypomorphic IL2RG gene mutations encoding the common gamma chain $[18,29]$. We therefore conclude that CD40L-CD40 interaction together with the cytokine production by T cells - and in particular, IL-21 as suggested from blocking experiments (data not shown) - are responsible for the B cell proliferation by $\alpha \mathrm{CD} 3 / \alpha \mathrm{CD} 28$-mediated T cell activation $[8,30]$. Patient \#4 can be clearly distinguished from these activation defects.

Finally, the B cells of CSR-like patients \#1, \#2, and \#3 showed clear overlap with the B cell-intrinsic CSR defects of AID- and UNG-deficient patients, where normal B cell proliferation and differentiation into PBs was found, as well as massive in vitro production of IgM without any $\operatorname{IgG}$ or $\operatorname{IgA}$. Absence of sIgG and $\operatorname{sIgA}$ on the B cells ex vivo supports the lack of Ig-isotype switched memory cells. The lack of IgG/A production with normal in vitro proliferation and differentiation defects resembles the cord blood phenotype; however, cord blood samples have a completely naïve B cell subset whereas AID- and UNG-deficient patients have clear population of circulating $\operatorname{sgD}{ }^{+} \mathrm{CD} 27^{+} \mathrm{B}$ cells. Another interesting finding is that patient \#1 as well as our AID-deficient patients produce a moderate amount of IgM when stimulated with $\alpha \mathrm{C} 40 / \mathrm{IL}-21$, this in contrast to all other samples. Potentially showing the failure in class switching, or a compensatory mechanism for the lack of IgG production.

Our approach to categorize CVID-patients according to functional $\mathrm{B}$ cell activation and differentiation may give additional information about the underlying signaling pathways contributing to the observed B cell defects in CVID.

Although a single gene defect may still underlie this distinct CSR-like CVID subgroup, our data already demonstrate variability in these CSR-like B cell defects, making a monogenetic cause rather unlikely. Even within the same PID subcategory, defects can lead to variable phenotypes, which could be the result of genotype (hypomorphic mutations), the microbial exposure, and/or the complex nature of the gene defect causing a disbalance or loss of strength of multiple activating signals. For instance, data from the recently described defects in the mTOR-AKT-PI3K pathway in humans and mice already hints to such variability in the outcome of functional B cell development [31-34]. In APDS, the observed dysglobulinemia may encompass a slight increase of $\operatorname{IgM}$ and decrease in $\operatorname{IgG}$ or IgG-subclass levels. Also, mutations in the CTLA4 gene have recently been shown to cause CVID with highly variable and incomplete penetrance $[35,36]$.
For our subgroup of functionally characterized CSR-like CVID patients, whole genome sequencing has been undertaken. Known PID genes according to the IUIS list of approved PIDs [37] did not show any defect in the CSR-like CVID cases to date. RNA expression arrays may for that reason be informative to define this subgroup in more detail to further explore whether a disbalance in B cell-activating signals or additional genes involved in CSR, may be involved.

In sum, our culture system to functionally test CVID patients by determining the capacity of peripheral blood B cells to proliferate and differentiate into activated Ig-secreting PBs may be useful to characterize hitherto undescribed functional PAD subgroups. Our data on a distinct CVID subgroup indicates the presence of B cell defects comparable with known CSR patients. Their recognition as a subgroup in functional terms may help to identify the underlying defects in B cell activation.

Authorship Contributions DJadK, EvL, and TWK designed the experiments. DJadK and MHJ performed and analyzed the experiments. DJadK, EvL, and TWK wrote the manuscript. SJ, KW, SS, and ItB provided patient material and critically read the manuscript.

Funding This manuscript was funded by "AMC research scholarship" provided to DJadK by the Academic Medical Centre of Amsterdam.

\section{Compliance with Ethical Standards}

Conflict of Interest The authors declare no commercial or financial conflict of interest.

Open Access This article is distributed under the terms of the Creative Commons Attribution 4.0 International License (http:// creativecommons.org/licenses/by/4.0/), which permits unrestricted use, distribution, and reproduction in any medium, provided you give appropriate credit to the original author(s) and the source, provide a link to the Creative Commons license, and indicate if changes were made.

\section{References}

1. Notarangelo LD. Primary immunodeficiencies. J Allergy Clin Immunol. 2010;125:S182-94.

2. Lim MS, Elenitoba-Johnson KS. The molecular pathology of primary immunodeficiencies. J Mol Diagn: JMD. 2004;6:59-83.

3. International Union of Immunological Societies Expert Committee on Primary, I, Notarangelo LD, Fischer A, Geha RS, Casanova JL, Chapel H, et al. Primary immunodeficiencies: 2009 update. J Allergy Clin Immunol. 2009;124:1161-78.

4. Durandy A, Kracker S, Fischer A. Primary antibody deficiencies. Nat Rev Immunol. 2013;13:519-33.

5. Vale AM, Schroeder Jr HW. Clinical consequences of defects in Bcell development. J Allergy Clin Immunol. 2010;125:778-87.

6. Durandy A, Revy P, Imai K, Fischer A. Hyper-immunoglobulin M syndromes caused by intrinsic B-lymphocyte defects. Immunol Rev. 2005;203:67-79.

7. Davies EG, Thrasher AJ. Update on the hyper immunoglobulin $\mathrm{M}$ syndromes. Br J Haematol. 2010;149:167-80. 
8. Korthauer U, Graf D, Mages HW, Briere F, Padayachee M, Malcolm S, et al. Defective expression of T-cell CD40 ligand causes X-linked immunodeficiency with hyper-IgM. Nature. 1993;361:539-41.

9. Revy P, Muto T, Levy Y, Geissmann F, Plebani A, Sanal O, et al. Activation-induced cytidine deaminase (AID) deficiency causes the autosomal recessive form of the Hyper-IgM syndrome (HIGM2). Cell. 2000;102:565-75.

10. Imai K, Zhu Y, Revy P, Morio T, Mizutani S, Fischer A, et al. Analysis of class switch recombination and somatic hypermutation in patients affected with autosomal dominant hyper-IgM syndrome type 2. Clin Immunol. 2005;115:277-85.

11. Imai K, Slupphaug G, Lee WI, Revy P, Nonoyama S, Catalan N, et al. Human uracil-DNA glycosylase deficiency associated with profoundly impaired immunoglobulin class-switch recombination. Nat Immunol. 2003;4:1023-8.

12. Chapel H, Lucas M, Lee M, Bjorkander J, Webster D, Grimbacher $\mathrm{B}$, et al. Common variable immunodeficiency disorders: division into distinct clinical phenotypes. Blood. 2008;112:277-86.

13. Mouillot G, Carmagnat M, Gerard L, Garnier JL, Fieschi C, Vince $\mathrm{N}$, et al. B-cell and T-cell phenotypes in CVID patients correlate with the clinical phenotype of the disease. J Clin Immunol. 2010;30:746-55.

14. Cunningham-Rundles C, Bodian C. Common variable immunodeficiency: clinical and immunological features of 248 patients. Clin Immunol. 1999;92:34-48.

15. aan de Kerk DJ, Jansen MH, ten Berge IJ, van Leeuwen EM, Kuijpers TW. Identification of B cell defects using age-defined reference ranges for in vivo and in vitro B cell differentiation. $\mathrm{J}$ Immunol. 2013;190:5012-9.

16. Driessen GJ, van Zelm MC, van Hagen PM, Hartwig NG, Trip M, Warris A, et al. B-cell replication history and somatic hypermutation status identify distinct pathophysiologic backgrounds in common variable immunodeficiency. Blood. 2011;118:6814-23.

17. Wehr C, Kivioja T, Schmitt C, Ferry B, Witte T, Eren E, et al. The EUROclass trial: defining subgroups in common variable immunodeficiency. Blood. 2008;111:77-85.

18. Kuijpers TW, Baars PA, Aan de Kerk DJ, Jansen MH, Derks IA, Bredius RG, et al. A novel mutation in CD132 causes X-CID with defective T-cell activation and impaired humoral reactivity. J Allergy Clin Immunol. 2011;128(1360-1363), e1364.

19. Berkowska MA, van der Burg M, van Dongen JJ, van Zelm MC. Checkpoints of B cell differentiation: visualizing Ig-centric processes. Ann N Y Acad Sci. 2011;1246:11-25.

20. LeBien TW, Tedder TF. B lymphocytes: how they develop and function. Blood. 2008;112:1570-80.

21. Bernasconi NL, Onai N, Lanzavecchia A. A role for Toll-like receptors in acquired immunity: up-regulation of TLR9 by BCR triggering in naive $\mathrm{B}$ cells and constitutive expression in memory $\mathrm{B}$ cells. Blood. 2003;101:4500-4.

22. Recher M, Berglund LJ, Avery DT, Cowan MJ, Gennery AR, Smart $\mathrm{J}$, et al. IL-21 is the primary common gamma chain-binding cytokine required for human B-cell differentiation in vivo. Blood. 2011;118:6824-35.
23. Angulo I, Vadas O, Garcon F, Banham-Hall E, Plagnol V, Leahy TR, et al. Phosphoinositide 3-kinase delta gene mutation predisposes to respiratory infection and airway damage. Science. 2013;342:866-71.

24. Lucas CL, Kuehn HS, Zhao F, Niemela JE, Deenick EK, Palendira $\mathrm{U}$, et al. Dominant-activating germline mutations in the gene encoding the $\mathrm{PI}(3) \mathrm{K}$ catalytic subunit p110delta result in $\mathrm{T}$ cell senescence and human immunodeficiency. Nat Immunol. 2014; 15:88-97.

25. Crank MC, Grossman JK, Moir S, Pittaluga S, Buckner CM, Kardava L, et al. Mutations in PIK3CD can cause hyper IgM syndrome (HIGM) associated with increased cancer susceptibility. J Clin Immunol. 2014;34:272-6.

26. Hamann D, Baars PA, Rep MH, Hooibrink B, Kerkhof-Garde SR, Klein MR, et al. Phenotypic and functional separation of memory and effector human CD8+ T cells. J Exp Med. 1997;186:1407-18.

27. Zheng S, Vuong BQ, Vaidyanathan B, Lin JY, Huang FT, Chaudhuri J. Non-coding RNA generated following lariat debranching mediates targeting of AID to DNA. Cell. 2015;161: 762-73.

28. Muramatsu M, Kinoshita K, Fagarasan S, Yamada S, Shinkai Y, Honjo T. Class switch recombination and hypermutation require activation-induced cytidine deaminase (AID), a potential RNA editing enzyme. Cell. 2000;102:553-63.

29. Kuijpers TW, van Leeuwen EM, Barendregt BH, Klarenbeek P, aan de Kerk DJ, Baars PA, et al. A reversion of an IL2RG mutation in combined immunodeficiency providing competitive advantage to the majority of CD8+ T cells. Haematologica. 2013;98:1030-8.

30. Durandy A, De Saint Basile G, Lisowska-Grospierre B, Gauchat JF, Forveille M, Kroczek RA, et al. Undetectable CD40 ligand expression on T cells and low B cell responses to CD40 binding agonists in human newborns. J Immunol. 1995;154:1560-8.

31. Zhang S, Readinger JA, DuBois W, Janka-Junttila M, Robinson R, Pruitt $\mathrm{M}$, et al. Constitutive reductions in $\mathrm{mTOR}$ alter cell size, immune cell development, and antibody production. Blood. 2011;117:1228-38.

32. Benhamron S, Pattanayak SP, Berger M, Tirosh B. mTOR activation promotes plasma cell differentiation and bypasses XBP-1 for immunoglobulin secretion. Mol Cell Biol. 2015;35:153-66.

33. Benhamron S, Tirosh B. Direct activation of mTOR in B lymphocytes confers impairment in B-cell maturation andloss of marginal zone B cells. Eur J Immunol. 2011;41:2390-6.

34. Limon JJ, Fruman DA. Akt and mTOR in B cell activation and differentiation. Front Immunol. 2012;3:228.

35. Schubert D, Bode C, Kenefeck R, Hou TZ, Wing JB, Kennedy A, et al. Autosomal dominant immune dysregulation syndrome in humans with CTLA4 mutations. Nat Med. 2014;20:1410-6.

36. Kuehn HS, Ouyang W, Lo B, Deenick EK, Niemela JE, Avery DT, et al. Immune dysregulation in human subjects with heterozygous germline mutations in CTLA4. Science. 2014;345:1623-7.

37. Al-Herz W, Bousfiha A, Casanova JL, Chatila T, Conley ME, Cunningham-Rundles $\mathrm{C}$, et al. Primary immunodeficiency diseases: an update on the classification from the international union of immunological societies expert committee for primary immunodeficiency. Front Immunol. 2014;5:162. 